\title{
Crítica literaria \\ Un texto útil, como fuente de motivación y enseñanza
}

\author{
Viviana Cristina Alfonso-Hernández \\ Investigadora \\ Centro de Estudios Martianos \\ Cuba \\ DOI: https://doi.org/10.15359/tdna.35-66.8 \\ Recibido: 14/5/2019
}

La vida y obra martiana es hoy, a pesar de lo turbulento, agitado y apresurado que se mueve el mundo, una fuente inagotable de sabiduría, conocimiento y una especie de refugio espiritual. Son muchos los investigadores, historiadores y periodistas que con sus trabajos han transitado y transitan por tan mágico universo; entre ellos destaco al intelectual cienfueguero Víctor Pérez-Galdós Ortiz, quien por más de diez años ha atendido dos programas en la radio cubana y la sección en la página web de Habana Radio sobre el Héroe Nacional; recibiendo por su acción, de manos de la Sociedad Cultural José Martí, el reconocimiento "Honrar, honra". Esta vez, el periodista se presenta ante el público lector con el texto: José Martí. Fuente de motivación y enseñanza, de la Colección Patria, perteneciente a la Editorial José Martí.

Calificado como un hombre de todos los tiempos, según propone el autor, Martí constituye una guía y motor impulsor para los cubanos y para hombres y mujeres de bien, en diferentes partes el mundo. Para demostrar esta hipótesis, el libro comienza con un resumen de la vida y labor del universal cubano; luego propone un recorrido por múltiples instituciones y sitios naturales e históricos relacionados o dedicados, de una manera u otra, a José Martí, y que se dedican a la investigación y promoción de su legado. En tal sentido, el discurso deviene testimonio del eterno homenaje de los nacidos en este archipiélago caribeño al patriota cubano.

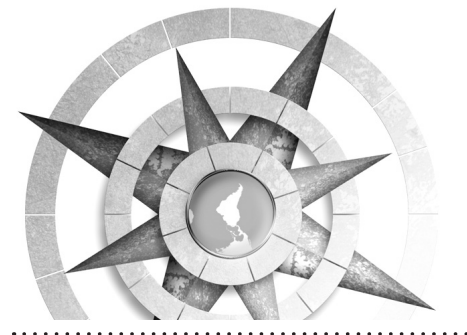

https://doi.org/10.15359/tdna.35-66.8

Dirigido fundamentalmente a un público neófito, que se inicia en el conocimiento del Apóstol nos da la posibilidad de sentirnos un poco más cerca del Maestro, al identificarnos con 
lugares que formaron parte de su ser y que hoy forman parte de nuestro día a día. Edificios, instituciones, monumentos, plazas y parques que nos acompañan en nuestra ajetreada cotidianidad, y que muchas veces ignoramos, desconocemos o no relacionamos directamente con el patriota cubano, son explicados brevemente en el texto, con el afán de una posterior profundización personal del tema.

Los lectores disfrutarán, con un lenguaje ameno, locuaz, claro y preciso, de la invitación que nos hace el investigador a recorrer, interesarnos e identificarnos con los sitios relacionados con el Héroe de Dos Ríos.

En el plano formal, el libro cuenta con dos epígrafes: Martí como fuente de motivación y Martí y su presencia en Cuba. Se destacan la edición de Elisa Pardo, el diseño y la composición de Enrique Mayol y la imagen de la portada, que, entre acuarelas, muestra la mitad de la silueta del rostro de un Martí pensativo y misterioso en cierto sentido, que, de alguna manera, invita al lector a adentrarse en el conocimiento y estudio de la huella de un hombre que desde el siglo XIX es ya presencia imprescindible en la historia del mundo.

La promoción de ese ideario martiano es el empeño que llevó a Pérez-Galdós Ortiz a seleccionar y ordenar el pensamiento del Maestro con el propósito de presentar un volumen para servicio de periodistas, profesores y estudiosos de la obra martiana y, de manera especial, a las nuevas generaciones, para así contribuir a su formación como cubanos, hombres y mujeres leales a su patria, a sus próceres y a la humanidad.

Este libro de síntesis apretada y explicaciones macizas es una prueba más de cuánta falta y cuánto bien nos hace conocer la vida y obra de nuestro Martí: los espacios, las personas, los hechos y detalles que alimentaron su sensibilidad, su imaginación y creatividad. 